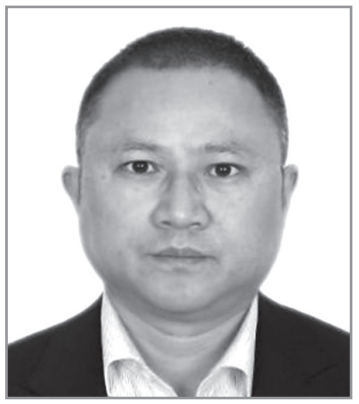

\title{
Li Faqiang
}

Peking University Law School

(5, Yiheyuan Road, Haidian District, Beijing, P.R. China)

https://orcid.org/0000-0001-9460-4697

\section{Elvina Abliakimova}

$\mathrm{PhD}$, Associate Professor,

Russian State University of Justice (69, Novocherjomushkinskaja St., Moscow,

Russian Federation)

https://orcid.org/0000-0003-0684-3378

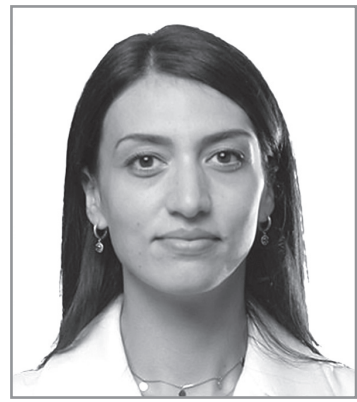

Faqiang, L., Abliakimova, E. (2020). Safe ports: law, theory, practice under conditions of the COVID-19 pandemic. Lex Portus, 4, 7-34. https://doi.org/10.26886/2524-101X.4.2020.1

\section{SAFE PORTS: LAW, THEORY, PRACTICE UNDER CONDITIONS OF THE COVID-19 PANDEMIC}

\section{ABSTRACT}

The article examines modern practical approaches to ensuring the safety of seaports as hubs of logistics centres for international trade and replacement points for ship crews under the conditions of the COVID-19 pandemic. The 
historical retrospective of the formation of anti-epidemic legal instruments to counteract the spread of particularly dangerous and rapidly spreading diseases is outlined. It is emphasized that the COVID-19 pandemic and the quarantine restrictions imposed by it in the states belong to the range of force majeure. The approaches of national legislations, international agreements, case law, and time charter pro-forma to the legal category of "safe port" are analyzed. Emphasis has been placed on shifting priorities in port security from those prevailing since the early 2000 s to terrorist, technical and navigational threats to threats related to the spread of the COVID-19 and to take measures to prevent the spread of the disease. The study develops the concept of ensuring a universal approach to the formation of protocols and best practices to combat the spread of COVID-19 and the introduction of increased financial sanctions in case of violation of the established rules.

The key words: port, security, crew change, legal regulation, shipping, maritime sector.

\section{Introduction}

The COVID-19 pandemic has had a significant impact on all areas of human activity around the world. One of the first industries to be at high risk was shipping. Multinational crews, the international nature of operations, and the need to ensure a stable supply of large consignments have become the factors that attracted the attention of all private actors involved in global shipping, the WHO, and national administrations. The COVID-19 aspect has identified significant threats to the spread of the disease in the maritime sector. The first mobile quarantine zones were large cruise liners with thousands of people on board. Port entry bans, strict quarantine requirements, testing, restrictions on communication, the need to isolate the infected, anti-epidemic measures, disinfection of premises, morbidity and mortality through COVID-19 have become a sad reality for the maritime sector in 2020 (Denyer \& O'Grady, 2020; Moriarty, et al., 2020; Prak Chan Thul, 2020). The force majeure of the pandemic led to the delays in the delivery of goods and breach of contract. The new 
coronavirus has caused emergencies in leading port states, calling for swift and effective action to prevent new infections.

In this situation, the security of ports - nodal logistics centres of international trade and replacement points for ship crews - has become a leading factor of paramount importance for modern world shipping. The ability of port states to provide reliable conditions for stable operation during a pandemic is currently an important factor in economic stability. The approaches taken to ensure it by the states have gradually removed the world's largest ports from the epidemic crisis but put on the agenda the systematization of such measures, development / updating of effective protocols and best practices for ensuring the epidemic well-being of ports, ships, and their crews. And these practices must become universal and effective because most of them have already been used in times of outbreaks of infectious diseases and have given good results. Their unification, detailed regulation of the sequence, and system of necessary actions, defined in the mandatory legal norms, and strengthened by severe financial sanctions in case of violation, will facilitate this. After all, today, the basic neglect of conventional sanitary norms has caused that COVID-19 has infected more than 20 million people in the world (Coronavirus disease (COVID-19). Situation Report - 205).

\section{Methodology}

The study focuses on identifying current trends in the development of legal instruments to ensure the epidemiological well-being of seaports and minimize industry losses from the COVID-19 pandemic. The author analyses the threats of the world shipping industry caused by the spread of COVID-19 and the consequences of the quarantine restrictions imposed by the countries. The genesis of the formation and the current state of legal regulation of counteraction to the spread of especially dangerous and rapidly spreading diseases are traced. The practical measures taken by the leading port states to ensure their epidemiological safety and establish a stable operation 
in a pandemic are considered. The study is based on the concept of universality of the approach to the formation of protocols and best practices to combat the spread of COVID-19 and the introduction of increased financial sanctions in case of violation of established rules.

\section{New virus - standard threats, port danger and force majeure}

At the end of 2019, a new type of coronavirus appeared in the Chinese city of Wuhan, the capital of Hubei Province. It spread rapidly throughout the country and the world, prompting the WHO to declare the outbreak a state of emergency and later a global pandemic due to its global spread. (WHO Director-General's opening remarks at the media briefing on COVID-19 - 11 March 2020).

Since the spread of the new virus, experts from various law firms have begun to point out certain risks to the maritime business. For example, in January of this year, Beth Bradley and John Agapitos emphasized that in the event of a worsening of the problem, the shipping industry should prepare for the same problems that arose during outbreaks of other diseases, such as other coronaviruses or Ebola. Experts also stressed that under a charterparty, charterers are under an obligation to nominate a safe port, an order with which the shipowners must comply with unless there is an unacceptable risk, or the port is known to be unsafe. Risks to the crew may render a port unsafe even where there is no risk of real damage to the vessel. Consequently, a contagious disease may legally make a port unsafe. The safety of a port depends greatly on whether proper precautions and protective measures are in place to ensure that a vessel can call at the port without risking infection of its crew (Bradley \& Agapitos, 2020). Representatives of Reed Smith warned about the need to review existing contracts as soon as possible, determine their force majeure circumstances, and provided recommendations on the inclusion of the COVID-19 pandemic in their circle (Simonds, et al., 2020). 
Starting from the spring 2020 rule-makers at the international, regional and national levels have started to issue acts, both obligatory and soft law, to set up respective legislative framework for response the COVID-19 pandemic with the respect to port safety.

For example, in April 2020 the UNCTAD issued a Policy Brief "COVID-19: A 10-Point Action Plan to Strengthen International Trade and Transport Facilitation in Times of Pandemic", which was built upon the experience of ongoing UNCTAD projects and the compilation of repositories of measures on cross-border movement of goods and persons. The Action Plan proposed concrete activities for Governments and international organizations to ensure epidemic prevention and, in particular, to secure and enhance the distribution of critical goods and to protect relevant service providers and supporting infrastructure.

On 14 April 2020, the European Commission adopted the Communication "Guidelines on protection of health, repatriation and travel arrangements for seafarers, passengers and other persons on board ships", which emphasizes (para 3) that "measures should be taken in EU ports to protect maritime transport personnel and port workers as well as seafarers and other persons on board while they embark and disembark. To ensure their health and safety, in accordance with EU law on health and safety at work, all risks should be assessed, and the appropriate preventive and protective measures put in place".

In the number of countries, the issue of force majeure caused by the COVID-19 pandemic has been resolved at the legislative level.

Actually, the COVID-19 pandemic led to highly exceptional conditions in the first quarter of 2020, with severe worldwide disruption of production processes and logistical chains. Closed factories, stricter border controls, and restrictions on personal freedom of movement have disrupted society around the globe (Throughput volume falls in an exceptional first quarter). Among other unfavourable tendencies, experts note the growing demand 
for discounts on port costs by line operators and cargo owners. The argument is pandemic. At the same time, every week there are reports of an increase in freight with a huge drop in fuel prices. Container ship operators also use a method of combating cost reductions in the event of falling bookings, such as blank sailings, i.e. cancelled flights or shipments, in which freight shipments consolidate but port revenues reduce accordingly. At the same time, the cost of operations in ports rises, while $15-20 \%$ of the workforce is hospitalized or quarantined, and the total administrative costs due to COVID-19 prevention measures have almost doubled (Netrebenko, 2020).

\section{Safe ports: a general legal framework}

A safe port is a normal condition of a chartering agreement under which the charterer guarantees the shipowner the safe stay of the vessel in the agreed port. The port must be safe at the time the vessel enters it, during the vessel's stay in and out of the port, and at the time when the vessel is instructed to follow the port.

This legal category is found in the documents accompanying maritime trade, quite often. A classic example is the standard BALTIME 39 as revised 2001 charter. According to its terms,

\section{"2. Trade}

The Vessel shall be employed in lawful trades for the 29 carriage of lawful merchandise only between safe ports 30 or places where the Vessel can safely lie always afloat 31 within the limits stated in Box 17. No live stock nor 32 injurious, inflammable or dangerous goods (such as 33 acids, explosives, calcium carbide, ferro silicon, 34 naphtha, motor spirit, tar, or any of their products) shall 35 be shipped";

and

\section{"14. Excluded Ports}

The Vessel shall not be ordered to nor bound to enter:

(A) any place where fever or epidemics are prevalent or to which the Master, officers and crew by law are not bound to follow the Vessel;

(B) any ice-bound place or any place where lights, lightships, marks and buoys are or are likely to be withdrawn by reason of ice on the Vessel's arrival or where there is risk that ordinarily the Vessel will not be able on account of ice to reach the place or to get out after having completed 
loading or discharging. The Vessel shall not be obliged to force ice. If on account of ice the Master considers it dangerous to remain at the loading or discharging place for fear of the Vessel being frozen in and/or damaged, he has liberty to sail to a convenient open place and await the Charterers' fresh instructions. Unforeseen detention through any of above causes shall be for the Charterers' account".

In fact, most time charters require the use of a vessel by charterers for passages between safe ports. For example, paragraph 3 of LINERTIME assumes that "the Vessel to be employed in lawful trades for the carriage of lawful merchandise only between good and safe ports or places...".

Convention on Facilitation of International Maritime Traffic, 1965, contains rules about public health and quarantine including sanitary measures for animals and plants (section 4 of the Annex to Convention). Moreover, Rule 4.1, which is a "standard", obliges States that are not parties to the International Health Regulations to "seek to apply those provisions of those rules which apply to international shipping". Public authorities of a State not Party to the International Health Regulations should endeavour to apply the relevant provisions of these Regulations to international shipping. Public authorities should seek the co-operation of shipowners to ensure compliance with any requirement that illness on a ship is to be reported promptly by radio to health authorities for the port for which the ship is destined, in order to facilitate provision for the presence of any special medical personnel and equipment necessary for health procedures on arrival.

The Maritime code of the People's Republic of China also contains several mentions of safe ports:

\section{"Article 91}

If, due to force majeure or any other causes not attributable to the fault of the carrier or the shipper, the ship could not discharge its goods at the port of destination as provided for in the contract of carriage, unless the contract provides otherwise, the Master shall be entitled to discharge the goods at a safe port or place near the port of destination and the contract of carriage shall be deemed to have been fulfilled. 
In deciding the discharge of the goods, the Master shall inform the shipper or the consignee and shall take the interests of the shipper or the consignee into consideration";

\section{"Article 134}

The charterer shall guarantee that the ship shall be employed in the agreed maritime transport between the safe ports or places within the trading area agreed upon.

If the charterer acts against the provisions of the preceding paragraph, the shipowner is entitled to cancel the charter and claim any losses resulting therefrom".

It is considered that the classic definition of a safe port was given in the Eastern City: "A port will not be safe unless, in the relevant period of time, a particular ship can reach it, use it and return from it without, in the absence of some abnormal occurrence, being exposed to danger which cannot be avoided by good navigation and seamanship" (Leeds Shipping Co Ltd v Societe Francaise Bunge).

This emphasizes, first of all, the relative nature of the requirements for the port. It must be safe for a particular vessel. From this point of view, a port that is safe for one vessel cannot be considered as such for another (Kalpin, 2010, p. 48). Such dependance on the specific vessel was, in particular, ruled in the Brostrom v Dreyfus: "The test of whether a port is safe in the physical sense and in the political sense, is whether it is safe for the particular ship (laden as it is contemplated that she will be laden and as she is, in fact, laden under the particulars of carriage in question), to enter and load or unload in the port in question" (Axel Brostrom \& Son v Dreyfus \& Co).

Requirements for a port to be considered a "safe port" are as follows:

- there must be safe access to the port, and it must be free from permanent obstruction. However safe a port may be in other respects, it is not "safe" if the vessel cannot reach it without serious risk of damage by ice, etc. A temporary obstruction, e.g. neap tides, does not, however, make a port unsafe; 
- it must be a port where the vessel can lie safely afloat at all states of the tide, unless it is customary and safe to load and/or discharge aground or there is special agreement to do so. Whereas the standard terms may require the vessel to "proceed to the loading port or place stated or as near thereto as she may safely get and lie always afloat", the terms will often be amended to permit a short-sea vessel to lie "safe aground";

- there must be adequate facilities for trade, including a safe shore landing of goods, proper wharves, warehouses and other establishments for dealing with the kind of cargo contemplated;

- it must be a politically safe port, free from any state of war or embargo;

- the ship, having reached the port (and discharged her cargo), must be able to leave safely, e.g. without having to lower or cut her masts to pass under a bridge.

Unless there is specific agreement to the contrary, the master is always entitled to refuse to enter a port which his vessel cannot safely reach (due to lack of sufficient water depth) without first lightening in a roadstead or other port, even if it is a customary method of discharge at the port (Safe ports and berths for cargo ships employment).

Generally, a port can be rendered unsafe due to:

- sandbanks and shallows

- obstructions such as wrecks

- an inadequate system at the port (such as weather warnings, mooring facilities and tug availability) to enable a ship to leave the port when weather conditions make it unsafe for the vessel to remain at berth

- political situation or war

- losses due to inordinate delay caused by temporary and permanent obstructions

- outbreak of an epidemic (Safe ports and berths in a nutshell).

As at all times, today port security is a significant factor in their stable operation. And if since the early 2000s the traditional threats 
to their functioning have been external and internal terrorist risks, technical, navigational, weather hazards, then at the end of 2019 and throughout 2020, the problems associated with the spread of COVID-19, and the use of measures to prevent the spread of the disease.

Sanitary control in seaports is an element of their sanitary regime and regulated by many international and national regulations. Its main tasks are the prevention of infectious and mass non-infectious diseases of the population of the states, prevention of harmful effects on humans of environmental factors, hygienic education and education of the population.

Usually, vessels are allowed to enter the port under the following protocol: sanitary and quarantine inspection of the vessel, as well as passengers and crew; permission (prohibition) for the right of free communication of the vessel, passengers and crew with representatives of the border service, customs authorities, etc.; sanitary and quarantine control of freight. Passage of persons at departure is carried out without sanitary-quarantine control, and passage of vessels - after sanitary-quarantine inspection, issue of the permission for the right to free navigation with the registration of the sea sanitary declaration (it is also made out at ship arrival).

\section{The historical aspect of the formation of the modern international legal basis for the epidemiological well-being of seaports}

Sanitary requirements for ships entering ports are standard practice, which is part of the general procedures for crossing state borders. It developed during the spread of pandemics of infectious diseases in Europe and the world. Some of the earliest recorded evidence of attempts to control human disease transmission via ships dates to the 14th century, when ports denied access to ships suspected of carrying the plague. In 1377, Venice and Rhodes denied access to ships carrying passengers infected with the plague, giving rise to the 
term "quarantine". On arrival, travellers were detained in isolation for 40 days before they were allowed to proceed to their final destination. Overcrowding on ships, filth and lack of personal hygiene were often associated with epidemics of rickettsial typhus fever. Preventive measures, such as quarantine, delousing and maintaining personal cleanliness by use of soap, were gradually adopted, and the incidence of typhus decreased (Guide to ship sanitation, 2011, p. vii, 1). The mentioned law of Venice stated all ships and passengers had to be stationed on the nearby island of San Lazzaro until the special health council gave them permission to enter the city. This led to the discrimination of ships and travellers from certain countries as well as other wrongdoing that was occurring in Venice regularly. Across the Adriatic Sea in Ragusa (present-day Dubrovnik, Croatia), however, the city's Great Council passed a ground-breaking law in 1377 to prevent the spread of the pandemic requiring all incoming ships and trade caravans arriving from infected areas to submit to 30 days of isolation. The legislation, Veniens de locis pestiferis non intret Ragusium vel districtum ("Those arriving from plague-infected areas shall not enter Ragusa or its district"), stipulated that anyone coming from pernicious places must spend a month in the nearby town of Cavtat or the island of Mrkan for the purpose of disinfection before entering the medieval walled city. Dubrovnik implemented a method that was not only just and fair, but also very wise and successful, and it prevailed around the world (Vuković, 2020).

Thus, sanitary control of ships in ports is one of the oldest and most important types of control carried out in the field of merchant shipping. For a long time, the states used solely national rules, which often led to economic difficulties, and sometimes paralyzed all trade in the state, as the essence of this control was actually limited to the establishment of quarantine ${ }^{1}$. In this regard, in the XIX century

1 The term "quarantine" comes from the Italian words - quarante giorni (abbreviated "quarantine"), that means a 40-day period during which a separate raid in Italy kept ships arriving from eastern countries. At the time, this was the only way to limit the spread of infectious diseases. In 1374, Italy legislated the principles of quarantine. 
the question arose about the need to create common, international sanitary rules. This was due to the cholera epidemic that broke out in India in 1817 and eventually affected Southeast Asia, the Middle East, East Africa and the Mediterranean coast of Europe, becoming the First Cholera Pandemic (Hayes, 2005, p. 214-219).

In 1851, the first International Sanitary Conference was convened in Paris, bringing together representatives of 12 European countries. But an agreement that would suit all parties failed to be concluded during its holding. The next Paris Conference in 1859 was also unsuccessful. Only in 1866 at the Third International Sanitary Conference in Constantinople, representatives of the world's leading countries concluded the International Sanitary Convention and adopted the International Quarantine Statute. They established maximum and minimum quarantine periods for smallpox, plague and cholera, clarified port sanitary rules and functions of quarantine stations, and determined the importance of epidemiological information in the implementation of international cooperation to prevent the spread of infections. In the future, such conferences became an important and fruitful form of international cooperation of European countries. However, the final edition was conducted in 1892 (Howard-Jones, 1975, p. 12-65; Ersoy, et al., 2011). The process of developing a strategy to combat deadly diseases was not easy, as evidenced by the fact that in 100 years since 1851, international conferences to meet the relevant international agreements met 22 times.

The legal basis for the sanitary regime of ports includes those adopted by the League of Nations in 1934, the International Agreement for dispensing with Bills of Health and the International Agreement for dispensing with Consular Visas on Bills of Health were signed in Paris. According to these documents, a vessel of a state party to this Convention is exempt from the grant of a sanitary patent (International sanitary regulations, 1952, p. 1).

Since the establishment of the World Health Organization (WHO) in 1948, the issues of the development and adoption of 
international regulations in the field of sanitary welfare have been referred to as its competence. Already at the IV session of the WHO Assembly in 1951, the first International Sanitary Rules were adopted, which aimed at preventing the spread of six infectious diseases: cholera, plague, yellow fever, smallpox, typhus and relapsing fever. Subsequently, the XXII session of the WHO Assembly in 1969 adopted the International Health Regulations, which amended in 1973 and 1981. The current version of the rules was adopted by the 58th session of the World Health Assembly on May 23, 2005, and On June 15, 2007, the new version came into force, replacing the 1969 version. 194 states undertook to comply with its rules. These rules formed the basis of the national sanitary rules of almost all modern states.

The purpose and scope of these International health regulations (IHR, 2005) are to prevent, protect against, control and provide a public health response to the international spread of disease in ways that are commensurate with and restricted to public health risks, and which avoid unnecessary interference with international traffic and trade. A distinctive feature of the new version of the rules was an open list of diseases for which the rules apply. The most dangerous infections, in addition to the very beginning of the identified plague, cholera and yellow fever, also include hemorrhagic fevers (Ebola, Lassa, Marburg), West Nile fever.

Articles 22(b) and 24(c) of the IHR 2005 require State Parties to take all practicable measures to ensure that international conveyance operators keep their conveyances free from sources of contamination and infection, and competent authorities are responsible for ensuring that facilities at international ports (e.g. potable water, eating establishments, public washrooms, appropriate solid and liquid waste disposal services) are kept in sanitary condition.

IHR, 2005 introduced new certification procedures for ships. The new certificates are called "Ship Sanitation Control Exemption Certificate / Ship Sanitation Control Certificate". They replaced the 
previous Deratting Certificate / Deratting Exemption Certificate, provided by the IHR, 1969.

In 1967, WHO first published the Guide to ship sanitation, which was subjected to minor amendments in 1987. In the past, the guide was directly referenced in the IHR (Article 14), and its purpose was to standardize the sanitary measures taken in relation to ships to safeguard the health of travellers and to prevent the spread of infection from one country to another (Guide to ship sanitation, 2011, p. 2). The current version of the Guide to ship sanitation was adopted in 2011. This document defines that a responsibility of port authorities is to provide the required equipment, facilities, expertise and materials so that ships can undertake operations (e.g. providing safe food and water, safely removing ballast and waste) in a sanitary manner. One or more agencies may fulfil the roles of the port authority, health authority and competent authority of a flag State under the IMO. Prevention of contamination at source to the maximum degree practicable is a key tenet of preventive control strategies. As ships load at ports, the port authorities play a vital role in protecting public health by seeking to provide the best practicable raw materials for ships. Authorities should clarify which entity has the Ship Sanitation Certificate and food inspection responsibilities.

\section{Main port safety actions under conditions of COVID-19 pandemic: stability of crew changes, anti-epidemic protocols and execution of contracts}

Due to the UNCTAD data the value of international trade in goods has declined by about 5 percent in Q1 2020 and is expected to decline further by 27 percent in Q2 2020. The annual decline is expected to be around 20 percent according to UNCTAD and between 13 and 32 percent according to the WTO (Global trade update, p. 2). Such significant fall of international trade directly affects maritime transport and ports. Since the beginning of the pandemic, many ports around the world have seen a drop-in cargo turnover, but not 
a halt, and in some cases even an increase. Thus, in Barcelona, the handling of containers decreased by $14 \%$, Ro-Ro cargo - by $17.3 \%$, and bulk - by $8.1 \%$. And only bulk cargo showed a slight increase of $0.4 \%$ (In March, freight traffic in the port of Barcelona decreased by $-8.3 \%)$. The head of the port of Casablanca, on the contrary, announced an increase of $14 \%$ in bulk foodstuffs (grain and legumes), as well as basic necessities, which in the early days of quarantine were swept from store shelves. Then, its gradation is followed by industrial goods such as metals, wood and equipment a decrease from 30 to $50 \%$, which, however, after quarantine should be the opposite - an increase. And only high-value goods associated with comforts, such as cars and domestic appliances, show a drop of $80 \%$, and these volumes will unlikely return quickly (Morocco increases grain handling by ports).

Significant restrictions that have become a reality in the COVID-19 pandemic have led to problems with changing ship crews, fulfilling the terms of contracts and even bunkering operations for ships. So, bunkering operations at Hong Kong will be affected by stricter Coronavirus Disease 2019 (COVID-19) measures from 29 July onwards. The Centre for Health Protection, an agency under the Department of Health in Hong Kong responsible for disease prevention and control, on Sunday (26 July) issued a circular to the maritime community. Crew change arrangement for passenger vessels and goods vessels without cargo operation in Hong Kong would be suspended with effect from July 29. The testing and quarantine arrangement for sea crew members of goods vessels coming to Hong Kong for cargo operation, air crew members and other persons exempted from quarantine requirement (exempted persons) arriving Hong Kong will be tightened. It said the changes were essential for maintaining the necessary operation of society and the economy, and for ensuring an uninterrupted supply of all daily necessities to the public (Hong Kong: Bunkering operations affected amidst tightening of COVID-19 measures). 
Singapore announced that effective immediately it was tightening its rules on crew changes occurring at its port. This comes after widespread reports of abuses and even possible tampering of test results. The Maritime and Port Authority released new protocols saying, "with immediate effect, MPA will give priority to applications from Singapore-registered ships and applications for sign-off crew only," while saying it would consider cases where seafarers were beyond their contracts without an extension from the port state or in cases of compassionate leave or being medically unfit. The rules for inbound crew to board a ship in Singapore say signing-on crew need to self-isolate for the 14-days before departing for Singapore, and that shipowners, managers, and agents must ensure accurate COVID-19 Polymerase Chain Reaction (PCR) tests. Seafarers are also being told that they must transfer directly to the ship upon arrival in Singapore, although some seafarers are reportedly hesitant to fly into Singapore because of the uncertainty of the situation (ICS Warns Failure to Follow Protocols Undermines Crew Change Efforts).

In the Port of Rotterdam the throughput of dry bulk in the first quarter 2020 amounted to 16.7 million tonnes. That is $14 \%$ less than in the same quarter in 2019. There was a substantial decrease of almost 3 million tonnes in the throughput of coal (-39.6\%). The main reason for this was that less power was generated from coal in Germany and the Netherlands. More electricity was generated from gas and wind because of the low gas price and large amounts of wind energy due to favourable weather conditions. Ore throughput rose by $15.7 \%$ (920K tonnes) (Throughput volume falls in an exceptional first quarter).

Container traffic at China's biggest ports fell for two weeks in a row in early April after a drop in overseas orders hit the nation's exports, according to the China Ports and Harbours Association. For the week starting April 6, the number of freight containers handled by China's eight largest container ports in Shanghai, Ningbo, Shenzhen, Guangzhou, Qingdao, Tianjin, Xiamen and Dalian dropped by 
five per cent from a year earlier, the association said in its weekly update released on Wednesday. This was the second consecutive week traffic fell after Chinese ports resumed some operations in late February, when the domestic coronavirus outbreak was beginning to be brought under control. Between March 30 and April 5, container traffic also fell 4.4 per cent from a week earlier, the first time the number dropped on a weekly basis since mid-February (Leng, 2020).

With this respect the safety of ports becomes not only the means of protection against COVID-19 pandemic itself, but also is focused on softening negative economic impact for the industry and ensuring swiftness of its future economic recovery.

Notably, that the essential share of port safety rules, issued by international actors, are made in form of a soft law instruments. For example, International Maritime Organization (IMO) have issued more than thirty circular letters since the outbreak of COVID-19 pandemic, that provide advice to IMO member states, seafarers and shipping on different protocols, ways and means of response to the COVID-19 related threats. Furthermore, respective circular letters and recommendations are reposited in the specific section of IMO web site (Coronavirus disease (COVID-19) Pandemic. IMO). In particular, it is ought to be highlighted such IMO's acts, as:

- Circular Letter No.4204/Add.8 of 14 April 2020 "Coronavirus (COVID-19) - Video meeting with port State control (PSC) regimes", which shared statements and relevant temporary guidance issued by the United States, The Acuerdo De Viña Del Mar And The Caribbean, Indian Ocean, Mediterranean, Paris And Tokyo MOUs relating vessels inspections, exams and documentation;

- Circular Letter No.4204/Add.21 of 8 June 2020 "Joint statement IMO-UNCTAD - Call for collaborative action in support of keeping ships moving, ports open and cross-border trade flowing during the COVID-19 pandemic";

- Circular Letter No.4204/Add.6 of 27 March 2020 "Preliminary list of recommendations for Governments and relevant national 
authorities on the facilitation of maritime trade during the COVID-19 pandemic";

- Circular Letter No.4204/Add.23 of 1 July 2020 "Coronavirus (COVID-19) - Recommendations for port and coastal States on the prompt disembarkation of seafarers for medical care ashore during the COVID-19 pandemic", etc.

UNCTAD, in its turn, have issued the Technical Note "Port Responsiveness in the fight against the "invisible" threat: COVID-19", which integrated best practices extracted from documents received from ports that are part of the UNCTAD TrainForTrade Network. Along with general anti-epidemic measures, that are common for any kind of industry or activity, the said Technical Note includes series of specific port-related measures, such as:

- Limit physical interaction between onboard and onshore staff. Ship crew should communicate with quayside staff by radio or telephone;

- Increase the use of digital documentation to limit human contact to the minimum;

- Establish a point of control in the perimeter of the port area to monitor temperature and related symptoms (automated temperature screening) and equip it with anti-bacterial solutions and sanitizers;

- Have a passenger information system for easy contact tracing and an isolated holding and testing area for COVID-19 symptomatic port users;

- Institute a protocol for disembarking passengers/crew requiring immediate medical care in coordination with the national health authority.

The Technical Note also have provided recommended crisis protocol that can be used as a guide on actions that should be implemented in relation to strictly defined crisis levels.

Besides, UNCTAD provides the list of links to available online resources from international organizations and industry groups that 
reposit measures on cross-border movement of goods and persons (Repositories of measures on cross-border movement of goods and persons). This initiative reasonably contributes sharing relevant recommendations and best practices in the field.

As it was mentioned, the EU response to COVID-19 pandemic concerning port safety issues was made through Communication from the Commission "Guidelines on protection of health, repatriation and travel arrangements for seafarers, passengers and other persons on board ships" of 14 April 2020. That communication provides five separate sections of recommendations focused on different aspects of port safety, including such fields as:

- repatriation of persons on board cruise ships and all other vessels (specifying recommendations for cruise ships, for all vessels concerning transit and disembarking passengers and crew and for other vessels going into lay-up);

- changeovers of crews;

- designated ports for crew changes;

- sanitary recommendations and ship supplies

- recommendation for additional COVID-19 updated reporting by ships approaching EU ports.

What is important, the Communication specifically emphasizes (para 4) that Member States should consult representative workers' and employers' organizations in the shipping and ports sectors when implementing measures included in these guidelines.

The important contribution in rulemaking process to set up framework for the port safety under conditions of COVID-19 pandemic is made by private actors represented by different international associations, NGOs, etc.

Recognizing that the maritime sector plays a critical role in keeping trade flows open in the global fight against COVID-19, 20 members of the Port Authorities Roundtable (PAR) from Asia, Europe, Middle East and North America in April 2020 to declare their commitment to ensuring their ports remain open amidst the 
current pandemic. The declaration, initiated by Singapore, calls for port authorities to collaborate and share best practices in ensuring that port operations can remain undisrupted (20 Port Authorities Signed Declaration to Keep Ports Open to Seaborne Trade to Support Fight Against the COVID-19 Pandemic). List of 20 PAR members who signed the declaration: Abu Dhabi Ports, Antwerp Port Authority, Bureau of Port and Harbor, Tokyo Metropolitan Government, Busan Port Authority, Guangzhou Port Authority, Hamburg Port Authority, Maritime and Port Authority of Singapore, Montreal Port Authority, Ningbo Municipal Port Administration Bureau, Port Authority of Thailand (Bangkok Port), Port of Barcelona, Port and Harbor Bureau, City of Yokohama, Port and Harbor Bureau, Kobe City Government, Port Klang Authority, Port of Long Beach, Port of Los Angeles, Port of Rotterdam, Port of Seattle, Shanghai Municipal Transportation Commission, Port of Le Havre (List of 20 PAR members who signed the declaration).

Under the umbrella of the World Ports Sustainability Program (WPSP), a guidance document has been developed to provide support for the implementation of actions to prepare and alleviate coronavirus-related contingencies for port authorities and port operators. The document is based on an initiative of the Port of Açu (Brazil) to coordinate, collect and summarise input by ports worldwide on their initiatives facing the coronavirus crisis. This international benchmark has been complemented with further contributions from IAPH member ports. The guidance document is dynamic and will be regularly revised using new and updated contributions from ports worldwide (Where do I find operational guidance as a port based on global best practice?). The document reflects a common approach to port industry problems caused by the COVID-19 pandemic. The goal is to provide support for the implementation of actions to prepare and alleviate coronavirusrelated contingencies for port terminals and other maritime trade players. In addition, the actions could foster open collaboration 
to mitigate the pandemic. This edition of the Guidance on ports' response to the corona virus pandemic is structured along a fourlayered approach, to present a methodology and a range of good practices regarding 1) immediate measures addressing port operations, governance and communication, 2) measures to protect the business and financial returns, 3) measures to support customers, stakeholders and community, and 4) measures for getting back to work (Verhoeven, et al., 2020, p. 1). But the direction does not contain any rules regarding legal liability for non-compliance with quarantine restrictions (only social mentioned). They are usually established by national legislation, but the practice of spreading the disease has shown their low effectiveness. It was probably caused by either a small number of sanctions or the usual disregard for mandatory practices. Likely, an increase in fines for non-compliance with quarantine requirements, negligence in disregarding antiepidemic standards will contribute to improving the epidemic wellbeing of ports and the possibility of their use as safe.

\section{Conclusions}

Consequently, the measures taken by the ports of the world, in general, ensured their reliable operation and safety in the COVID-19 pandemic. Changes in freight turnover (up or down) were determined due to changes in demand and changes in industrial production and goods turnover in the states. The inclusion of quarantines established in the states as force majeure contributed to the stabilization of contractual practice. Rapidly updated national standard protocols for controlling the spread of infectious diseases have gradually brought the industry out of the crisis. And their unification at the level of international institutions has contributed to the global dissemination of best practices. However, in our opinion, national standard protocols should be provided with increased financial sanctions imposed by national legislation and aimed at strict compliance with the established anti-epidemic requirements. 


\section{REFERENCES}

20 Port Authorities Signed Declaration to Keep Ports Open to Seaborne Trade to Support Fight Against the COVID-19 Pandemic. Maritime and Port Authority of Singapore. Retrieved June 24, 2020 from: https://www.mpa.gov.sg/web/portal/home/media-centre/news-releases/ detail/8ef344f7-89ab-4d4c-99ba-a2c73532d2b4

Axel Brostrom \& Son v Dreyfus \& Co (1932) 44 L.L.L. Rep 136. Charterpartycases. com. Retrieved June 24, 2020 from: https://charterpartycases.com/ case/182-axel-brostrom-son-v-dreyfus-co-1932-44-1-1-1-rep-136

BIMCO uniform time-charter (as revised 2001). Code name: "BALTIME 1939". Ships for sale. Retrieved June 24, 2020 from: https://shipsforsale.su/upload/ materials/1612291321565991.pdf

Bradley, B., Agapitos, J. (2020). Shipping needs to prepare for coronavirus restrictions, warns Hill Dickinson. Hill Dickinson. Retrieved June 26, 2020 from: https://www.hilldickinson.com/insights/news/ shipping-needs-prepare-coronavirus-restrictions-warns-hill-dickinson

Circular Letter No.4204/Add.6 of 27 March 2020, Preliminary list of recommendations for Governments and relevant national authorities on the facilitation of maritime trade during the COVID-19 pandemic (International Maritime Organization). The official web-site of the International Maritime Organization. Retrieved June 24, 2020 from: http://www.imo.org/en/MediaCentre/ HotTopics/Documents/COVID\%20CL\%204204\%20adds/Circular\%20 Letter\%20No.4204-Add.16\%20-\%20Coronavirus\%20(Covid\%2019)\%20 -\%20Covid-19\%20Related $\% 20$ Guidelines $\% 20$ For $\% 20$ Ensuring\%20A\%20 Safe\%20Shipboard.pdf

Circular Letter No.4204/Add.8 of 14 April 2020, Coronavirus (COVID-19) Video meeting with port State control (PSC) regimes (International Maritime Organization). The official web-site of the International Maritime Organization. Retrieved June 24, 2020 from: http://www.imo.org/en/MediaCentre/ HotTopics/Documents/Circular\%20Letter\%20No.4204-Add.8\%20$\% 20$ Coronavirus $\% 20$ Video $\% 20$ Meeting $\% 20$ With $\% 20$ Port $\% 20$ State $\%$ 20Control.pdf

Circular Letter No.4204/Add.21 of 8 June 2020, Joint statement IMO-UNCTAD Call for collaborative action in support of keeping ships moving, ports open and cross-border trade flowing during the COVID-19 pandemic (International Maritime Organization). The official web-site of the International Maritime Organization. Retrieved June 25, 2020 from: http://www.imo.org/en/ 
MediaCentre/HotTopics/Documents/COVID\%20CL\%204204\%20adds/ Circular\%20Letter\%20No.4204-Add.21\%20-\%20Joint\%20Statement\% 20Imo-Unctad\%20-\%20Call\%20For\%20Action\%20Keeping\%20Ships\% 20Moving.pdf

Circular Letter No.4204/Add.23 of 1 July 2020, Coronavirus (COVID-19) Recommendations for port and coastal States on the prompt disembarkation of seafarers for medical care ashore during the COVID-19 pandemic (International Maritime Organization). The official web-site of the International Maritime Organization. Retrieved July 25, 2020 from: http://www.imo.org/ en/MediaCentre/HotTopics/Documents/COVID\%20CL\%204204\%20 adds/Circular\%20Letter\%20No.4204-Add.23\%20-\%20Coronavirus\% 20(Covid-19)\%20-\%20Recommendations\%20For\%20Port $\% 20$ And $\%$ 20CoastalStates $\% 200$ \% $\% 20$ medical $\% 20$ care.pdf

Communication on Guidelines on protection of health, repatriation and travel arrangements for seafarers, passengers and other persons on board ships 2020/C 119/01 (European Commission). OJ C 119. 14.4.2020. P. 1-8.

Convention on Facilitation of International Maritime Traffic, 1965 (International Maritime Organization). Treaties.un.org. Retrieved June 24, 2020, from: https://treaties.un.org/doc/Publication/UNTS/Volume\%20591/volume-591-I8564-English.pdf

Coronavirus disease (COVID-19). Situation Report - 205. The official website of the World Health Organization. Retrieved August 13, 2020 from: https://www.who.int/docs/default-source/coronaviruse/situation-reports/20200812-covid-19-sitrep-205.pdf?sfvrsn=627c9aa8_2

Coronavirus disease (COVID-19) Pandemic. IMO. The official web-site of the International Maritime Organization. Retrieved June 25, 2020 from: http:// www.imo.org/en/MediaCentre/HotTopics/Pages/Coronavirus.aspx

COVID-19: A 10-Point Action Plan to Strengthen International Trade and Transport Facilitation in Times of Pandemic. Policy Brief. 2020. No. 79. April (UNCTAD). The official web-site of the UNCTAD. Retrieved June 25, 2020 from: https://unctad.org/en/PublicationsLibrary/presspb2020d3_en.pdf

Denyer, S., O'Grady, S. (2020). Passengers quarantined on cruise ship are desperate to escape coronavirus that infected 64 fellow travelers. The Washington Post. Retrieved June 25, 2020 from: https://www.washingtonpost.com/world/ asia_pacific/honeymooner-among-61-people-on-cruise-ship-confirmedas-having-coronavirus/2020/02/07/30a980b4-4961-11ea-8a1f-de1597be 6cbc_story.html 
Ersoy, N., Yuksel, G., Aslihan, A. (2011). International Sanitary Conferences from the Ottoman perspective (1851-1938). Hygiea Internationalis an Interdisciplinary Journal for the History of Public Health, 10(1), 53-79. DOI: 10.3384/hygiea.1403-8668.1110153

Global trade update. 2020. June (UNCTAD). The official web-site of the UNCTAD. Retrieved June 25, 2020 from: https://unctad.org/en/PublicationsLibrary/ ditcmisc2020d2_en.pdf

Guide to ship sanitation, 2011 (World Health Organization). The official website of the World Health Organization. Retrieved May 25, 2020 from: https://apps.who.int/iris/bitstream/handle/10665/43193/9789241546690_eng. pdf? sequence $=1$

Hayes, J.N. (2005). Epidemics and Pandemics: Their Impacts on Human History. Santa Barbara, CA: ABC-CLIO.

Hong Kong: Bunkering operations affected amidst tightening of COVID19 measures. Manifold Times. Retrieved July 28, 2020 from: https://www.manifoldtimes.com/news/hong-kong-bunkering-operations-affected-amidst-tightening-of-covid-19-measures/

Howard-Jones, N. (1975). The scientific background of the International Sanitary Conferences, 1851-1938. World Health Organization. Retrieved June 23, 2020 from: https://apps.who.int/iris/bitstream/handle/10665/62873/14549_eng. pdf? sequence $=1$

ICS Warns Failure to Follow Protocols Undermines Crew Change Efforts. The Maritime Executive. Retrieved July 25, 2020 from: https://www.maritime-executive.com/article/ics-warns-failure-to-followprotocols-undermines-crew-change-efforts

In March, freight traffic in the port of Barcelona decreased by $-8.3 \%$. InforMare. http:/www.informare.it/news/gennews/2020/20200588-porto-Barcellona-traffico-marzo-2020uk.asp

International Agreement for dispensing with Bills of Health, 1934 (League of Nations). Treaty Series, CLXXXIII, 153.

International Agreement for dispensing with Consular Visas on Bills of Health, 1934 (League of Nations). Treaty Series, CLXXXIII, 145, and CXCVII, 386.

International health regulations, 1969 (World Health Organization). The official web-site of the World Health Organization. Retrieved May 25, 2020 from: https://apps.who.int/iris/bitstream/handle/10665/96616/9241580070. pdf? sequence $=1$ 
International health regulations, 2005 (World Health Organization). The official web-site of the World Health Organization. Retrieved May 25, 2020 from: https://apps.who.int/iris/bitstream/handle/10665/246107/9789241580496eng.pdf? sequence $=1$

International sanitary regulations, 1952 (World Health Assembly). The official web-site of the World Health Organization. Retrieved April 20, 2020 from: https://apps.who.int/iris/bitstream/handle/10665/85636/Official_record37_ eng.pdf? sequence $=1 \&$ isAllowed $=y$

Kalpin, A.G. (2010). Bezopasnye porty i prichaly pogruzki ili vygruzki v dogovore frahtovanija morskih sudov [Safe ports and berths for loading or unloading in the ship charter agreement]. Pravo. Zhurnal Vysshej shkoly jekonomiki. [Law. Journal of the Higher School of Economics], 2, 47-56. [in Russian].

Leeds Shipping Co Ltd v Societe Francaise Bunge (The Eastern City) [1958] 2 Lloyd's Rep 127.

Leng,S.(2020).Coronavirus: containertrafficatChina'stopeightportsplungesinearly April as pandemic hits overseas orders. The Coronavirus pandemic. Retrieved April 20, 2020 from: https://www.scmp.com/economy/china-economy/ article/3080041/coronavirus-container-traffic-chinas-top-eight-ports-plunges

LINERTIME 2015. Deep Sea Time Charter. Ships for sale. Retrieved April 20, 2020 from: https://shipsforsale.su/upload/materials/1612291330279693.pdf

List of 20 PAR members who signed the declaration. Maritime and Port Authority of Singapore. Retrieved June 24, 2020 from: https:/www.mpa.gov.sg/web/

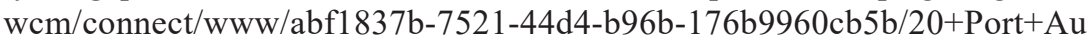
thorities+Signed+Declaration+Against+the+COVID-19+Pandemic_Annex. pdf?MOD=AJPERES

Maritime Code of the People's Republic of China, 1992 (28th Meeting of the Standing Committee of the Seventh National People's Congress). China Daily Report, No. FBIS-CHI-92-235, 13-38.

Moriarty, L.F., Plucinski, M.M., Marston, B.J., et al. (2020). Public Health Responses to COVID-19 Outbreaks on Cruise Ships - Worldwide, February-March 2020. MMWR Morb Mortal Wkly Rep, 69, 347-352. DOI: http://dx.doi.org/10.15585/mmwr.mm6912e3externalicon

Morocco increases grain handling by ports. PortSEurope. Retrieved June 19, 2020 from: https://www.portseurope.com/morocco-increasesgrain-handling-by-ports/

Netrebenko, A. (2020). Zhizn' portov v novoj real'nosti [Port's life in a new reality]. Centr transportnyh strategij. [Center of Transport Strategies]. Retrieved 
July, 21, 2020 from: https://cfts.org.ua/blogs/zhizn_portov_v_novoy_realnosti_550?fbclid=IwAR3h_rfOmv4IrzKIz4Wsqxme7XchiXmLPMdSQGbgXa-wYBFNTzUnqIV3xZU [in Russian].

Prak Chan Thul (2020). Cruise passengers shunned over coronavirus to head home after Cambodia reprieve. Reuters. Retrieved June 25, 2020 from: https:// www.reuters.com/article/us-china-health-cambodia-cruiseship/cruise-shipshunned-over-coronavirus-fears-arrives-in-cambodia-idUSKBN20702I

Repositories of measures on cross-border movement of goods and persons (UNCTAD). The official web-site of the UNCTAD. Retrieved June 25, 2020 from: https://unctad.org/en/Pages/Coronavirus/measures-affecting-cross-border-movement-of-goods-and-persons.aspx

Simonds, C., Burgess, V., Zwilling, E. (2020). Coronavirus and Content: The Impact of COVID-19 on the Development, Financing, Production, and Exploitation of Media Content. Reed Smith. Retrieved July, 13, 2020 from: https://www.reedsmith.com/en/perspectives/2020/03/coronavirusand-content-the-impact-of-covid19

Safe ports and berths for cargo ships employment. Generalcargoship.com. Retrieved July, 13, 2020 from: http://www.generalcargoship.com/safe-portsand-berths.html

Safe ports and berths in a nutshell. The West of England P\&I Club. Retrieved July, 13, 2020 from: https:/www.westpandi.com/ getattachment/bda5d2f7-8283-43e1-abbb-9727e7c7a0cb/safe_ports and_berths_4pp_v2_lr.pdf

Technical Note Port Responsiveness in the fight against the "invisible" threat: COVID-19 (2020) (UNCTAD). Traine for Trade. Retrieved June 25, 2020 from: https://ftt.unctad.org/ports-covid-19/

Throughput volume falls in an exceptional first quarter. Port of Rotterdam. Retrieved June, 15, 2020 from: https:/www.portofrotterdam.com/ en/news-and-press-releases/throughput-volume-falls-in-an-exceptional-firstquarter

Verhoeven, P., Michail, A., Major, T. (2020). WPSP COVID-19 guidance document for ports. WORLD PORTS COVID19 INFORMATION PORTAL. Retrieved June 23, 2020 from: https://sustainableworldports.org/wp-content/ uploads/2020-05-18-WPSP-COVID19-Guidance-FIN.pdf

Vuković, K. (2020). Dubrovnik: the medieval city designed around quarantine. BBC Travel. Retrieved June, 15, 2020 from: http://www.bbc.com/travel/ story/20200421-dubrovnik-the-medieval-city-designed-around-quarantine 
Where do I find operational guidance as a port based on global best practice? WORLD PORTS COVID19 INFORMATION PORTAL. Retrieved June 23, 2020 from: https://sustainableworldports.org/world-ports-covid19-information-portal/

WHO Director-General's opening remarks at the media briefing on COVID-19 11 March 2020. World Health Organization. Retrieved June 23, 2020 from: https://www.who.int/dg/speeches/detail/who-director-general-s-opening-remarks-at-the-media-briefing-on-covid-19---11-march-2020

\section{Фачан Л., Аблякімова Е. Безпечні порти: право, теорія, практика в умовах пандемії COVID-19. - Статmя.}

У статті досліджено сучасні практичні підходи до забезпечення безпеки морських портів як вузлових логістичних центрів міжнародної торгівлі та пунктів заміни екіпажів суден в умовах пандемії COVID-19. Проаналізовано загрози світовій індустрії морських перевезень, що викликані поширенням захворюваності на COVID-19, та наслідки запроваджених країнами карантинних обмежень. Підкреслюється, що санітарний контроль у морських портах $є$ елементом їх правового режиму. Його головними завданнями $€$ профілактика інфекційних та масових неінфекційних захворювань населення держав, запобігання шкідливого впливу на людину факторів середовища проживання, гігієнічне виховання і освіта населення. Окреслено історичну ретроспективу формування протиепідемічних правових інструментів для протидії розповсюдженню особливо небезпечних та швидко поширюваних захворювань. Підкреслено, що пандемія COVID-19 та встановлені через неї карантинні обмеження у державах належать до кола форс-мажорних обставин. Аналізуються підходи національних законодавств, міжнародних угод, судової практики, наукових досліджень та проформ тайм-чартерів до правової категорії “безпечний порт”. Акцентовано увагу та зміні пріоритетів у забезпеченні безпеки портів з таких, що превалювали з початку 2000-х років терористичних, технічних та навігаційних загроз на загрози, пов'язані з поширенням COVID-19 та вжиття заходів з метою недопущення поширення захворюваності. Розглянуто практичні заходи, здійснені провідними державами портів з метою забезпечення їх епідеміологічної безпеки та налагодження стабільної роботи в умовах пандемії. У статті формується концепція забезпечення універсальності підходу до формування протоколів і кращих практик протидії поширенню COVID-19 та запровадженні підвищених фінансових санкцій у разі порушення встановлених правил.

Ключові слова: порт, безпека, зміна екіпажів, правове регулювання, судноплавство, морська галузь. 
Фачан Л., Аблякимова Э. Безопасные порты: право, теория, практика в условиях пандемии COVID-19. - Статья.

В статье исследованы современные практические подходы к обеспечению безопасности морских портов как узловых логистических центров международной торговли и пунктов смены экипажей судов в условиях пандемии COVID-19. Проанализированы угрозы мировой индустрии морских перевозок, вызванные распространением заболеваемости COVID-19, и последствия введенных странами карантинных ограничений. Подчеркивается, что санитарный контроль в морских портах является элементом их правового режима. Его главными задачами являются профилактика инфекционных и массовых неинфекционных заболеваний населения государств, предотвращение вредного воздействия на человека факторов среды обитания, гигиеническое воспитание и образование населения. Определена историческая ретроспектива формирования противоэпидемических правовых инструментов для противодействия распространению особо опасных инфекционных заболеваний. Подчеркивается, что пандемия COVID-19 и установленные в связи с ней карантинные ограничения в государствах относятся к числу форс-мажорных обстоятельств. Анализируются подходы национальных законодательств, международных соглашений, судебной практики, научных исследований и проформ тайм-чартеров к правовой категории “безопасный порт". Акцентировано внимание на изменении приоритетов в обеспечении безопасности портов от превалировавших с начала 2000-х годов террористических, технических и навигационных угроз до угроз, связанных с распространением COVID-19 и принятии мер с целью недопущения распространения заболеваемости. Рассмотрены практические меры, предпринятые ведущими государствами портов с целью обеспечения их эпидемиологической безопасности и налаживания стабильной работы в условиях пандемии. В статье формируется концепция обеспечения универсальности подхода к формированию протоколов и лучших практик противодействия распространению COVID-19 и введения повышенных финансовых санкций в случае нарушения установленных правил.

Ключевые слова: порт, безопасность, смена экипажей, правовое регулирование, судоходство, морская отрасль. 